\title{
The emerging role of phosphoinositide clustering in
}

\section{intracellular trafficking and signal transduction [version 1;}

\section{peer review: 4 approved]}

\author{
Laura Picas ${ }^{1}$, Frederique Gaits-Iacovoni², Bruno Goud ${ }^{3}$ \\ ${ }^{1}$ Centre de Biochimie Structurale, CNRS UMR 5048, INSERM U1054, Université de Montpellier, Montpellier, France \\ 2INSERM, UMR1048, Université Toulouse III, Institut des Maladies Métaboliques et Cardiovasculaires, Toulouse, France \\ 3Institut Curie, PSL Research University, CNRS UMR 144, Paris, France
}

V1 First published: 31 Mar 2016, 5(F1000 Faculty Rev):422

https://doi.org/10.12688/f1000research.7537.1

Latest published: 31 Mar 2016, 5(F1000 Faculty Rev):422

https://doi.org/10.12688/f1000research.7537.1

\section{Open Peer Review}

Approval Status
version 1
p1 Mar 2016
articles are commissioned and peer reviewed
before publication to ensure that the final,
published version is comprehensive and
accessible. The reviewers who approved the final
version are listed with their names and
affiliations.

1. Tamas Balla, National Institutes of Health, Bethesda, USA

2. Vytas A Bankaitis, Texas A\&M Health Science Center, College Station, USA

3. Volker Haucke, Leibniz-Institut für Molekulare Pharmakologie (FMP), Berlin, Germany

4. Peter Mayinger, Oregon Health \& Science University, Portland, USA

Any comments on the article can be found at the 
end of the article.

Corresponding author: Bruno Goud (bruno.goud@curie.fr)

Competing interests: The authors declare that they have no competing interests.

Grant information: This work was supported by grants from the Agence Nationale de la Recherche (ANR) (ANR-13-BSV2-0004-01) and the ERC (MYODYN, \# 339847).

The funders had no role in study design, data collection and analysis, decision to publish, or preparation of the manuscript.

Copyright: $\odot 2016$ Picas L et al. This is an open access article distributed under the terms of the Creative Commons Attribution License, which permits unrestricted use, distribution, and reproduction in any medium, provided the original work is properly cited.

How to cite this article: Picas L, Gaits-Iacovoni F and Goud B. The emerging role of phosphoinositide clustering in intracellular trafficking and signal transduction [version 1; peer review: 4 approved] F1000Research 2016, 5(F1000 Faculty Rev):422 https://doi.org/10.12688/f1000research.7537.1

First published: 31 Mar 2016, 5(F1000 Faculty Rev):422 https://doi.org/10.12688/f1000research.7537.1 


\section{Introduction}

Phosphoinositides (PIs) are essential phospholipids that control, either directly or indirectly, multiple cellular functions including membrane trafficking, signal transduction, cell growth, cytoskeletal dynamics, lipid transport/exchange between organelles, and the regulation of transmembrane proteins ${ }^{1,2}$. PIs are the phosphorylated products of phosphatidylinositol. The reversible phosphorylation of the inositol ring at positions 3, 4, and 5 gives rise to the seven PI isoforms identified in eukaryotic cells (Figure 1). Inter-conversion of the phosphate group(s) is selectively tuned by numerous kinases and phosphatases, precisely regulated in space and time ${ }^{3}$ (Figure 1). The active metabolism of PIs is intimately linked to their role as precursors of second messengers during signal transduction ${ }^{4}$. The accumulation of the different PI species in specific membrane compartments is also directly related to their role in vesicular trafficking including endocytosis and exocytosis, endosome dynamics and trafficking from and towards the Golgi, among many others ${ }^{5}$ (Figure 1). Proteins with multiple trafficking functions are targeted to various membrane compartments based on the selective recognition of their PI-binding motifs. The distribution of protein residues folded in a 3D structure provides the PI-binding motifs with a "PI code", which is based on the stereospecific recognition of the unique phosphate group's organization around the inositol ring $^{6}$ (Figure 1). There are at least 11 different structured motifs with a wide range of affinities and specificities for the different PI species. They include the PH (pleckstrin homology), the FYVE (Fab1, YOTB, Vac1, and EEA1), the PX (Phox homology), the ANTH and ENTH (사180 and Epsin N-terminal homology), and the FERM (4.1, ezrin, radixin, moesin) modules.

\section{PIs and the lateral organization of membranes: the needle in a haystack}

Cellular membranes are highly heterogeneous composites built of different types of lipids and proteins. For instance, in eukaryotic cells, more than 1000 different lipid species build up the different membrane compartments ${ }^{7}$. Lipid molecules freely diffuse in the 2D membrane plane $\left(\mathrm{D} \sim 2.6 \times 10^{-7} \mathrm{~cm}^{2} \cdot \mathrm{s}^{-1}\right)^{8}$ and interact with protein effectors based on their association $\left(K_{\text {on }}\right)$ and dissociation $\left(K_{\text {off }}\right)$ rates. As a result, lipid-protein interactions are, in general, highly dynamic and thus strongly depend on their respective local concentration.

PIs constitute less than $1 \%$ of the steady-state cell lipids ${ }^{7}$, yet they work as unique docking sites for the multiple PI effectors on membranes, which in turn either compete or cooperate with each other to interact with downstream partners and elicit specific responses. Thus, what are the driving mechanisms that ensure such a thorough spatiotemporal recognition and membrane association of host PI-binding motifs?

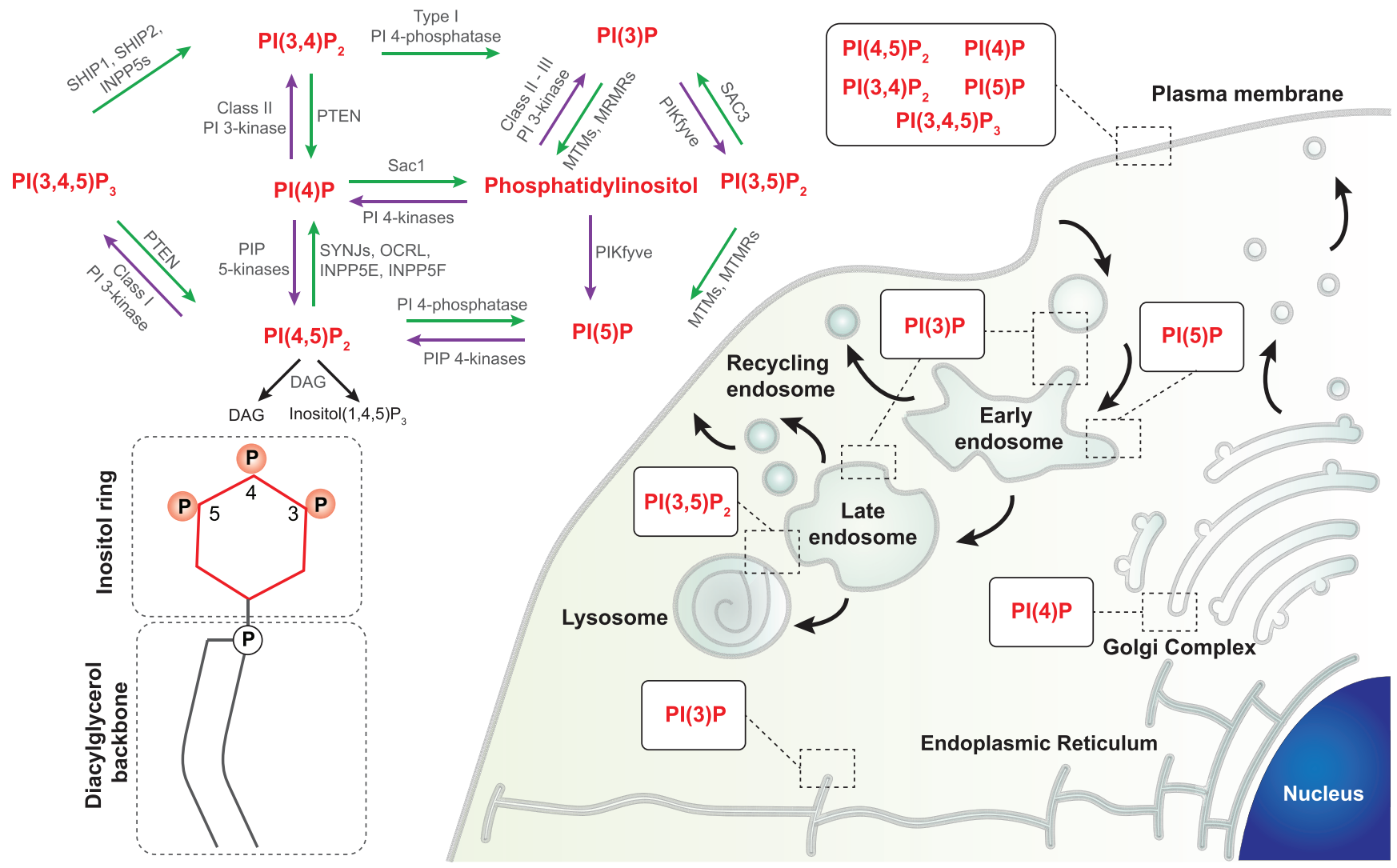

Figure 1. The seven phosphoinositide isoforms identified in eukaryotic cells are phosphorylated derivatives of phosphoinositols, which can be metabolized by different phosphatases and kinases. Representation of the phosphatidylinositol phospholipid structure: the inositol ring can be phosphorylated in three different positions and is linked to a diacylglycerol backbone by a phosphodiester linker. Schematics of the localization of the different PI isoforms on the cellular compartments. 
An attractive hypothesis is that PIs might be organized as specialized membrane subdomains with distinct organelle localizations ${ }^{5}$. PI pools within the same compartment are locally synthesized thanks to the spatiotemporal regulation of different PI-metabolizing enzymes $^{3,5}$. In addition, small GTPases of the ARF and RAB family also contribute to the generation and regulation of PI turnover on membranes ${ }^{9}$.

Considering the diffusion coefficient of lipid molecules within the membrane plane, it is likely that complementary mechanisms need to operate in order to spatially preserve the turnover of different PI subdomains. Indeed, several mechanisms have been reported in the literature to play roles as selective and reversible PI sinks by locally sequestering and releasing PIs. This is the case for the myristoylated alanine-rich C-kinase substrate (MARCKS) protein and the growth-associated protein $43(\mathrm{GAP} 43)^{10}$. The unstructured basic cluster on the effector domain of the MARCKS protein is able to bind up to at least three $\mathrm{PI}(4,5) \mathrm{P}_{2}$ molecules by means of nonspecific electrostatic interactions at physiologic $\mathrm{pH}$. The $\mathrm{Ca}^{2+} /$ calmodulin complex reversibly controls the association of MARCKS with the plasma membrane ${ }^{11}$. Interestingly, a growing number of studies report the local enrichment of PI subdomains independently of the catalytic activity of PI-metabolizing enzymes. Jahn and co-workers have shown that the SNAP receptor protein syntaxin-1A co-clusters with $\mathrm{PI}(4,5) \mathrm{P}_{2}$ via electrostatic interactions with its juxtamembrane polybasic sequence ${ }^{12}$. The segregation of $\mathrm{PI}(4,5) \mathrm{P}_{2}$ microdomains by syntaxin-1A has been proposed to work as a molecular beacon at sites of synaptic vesicle docking during exocytosis ${ }^{13}$. Similar polybasic clusters to that of the MARCKS protein or syntaxin-1A are found in the cytosolic membrane interface of many plasma membrane proteins ${ }^{14,15}$, including the epidermal growth factor receptor (EGFR) and the NMDA receptor as well as the voltage-gated potassium and calcium ion channels ${ }^{11}$. In vitro studies have shown that divalent cations such as $\mathrm{Ca}^{2+}$ are also capable of clustering together $\mathrm{PI}(4,5) \mathrm{P}_{2}$ molecules, although the exact correlation with the activity of ion channels inside the cell has yet to be established. Following in vitro approaches on giant unilamellar vesicles (GUVs), clustering of $\mathrm{PI}(4,5) \mathrm{P}_{2}$ was initially reported for ezrin ${ }^{16}$. Later on, using the yeast endocytic F-BAR/ BAR domains, Lappalainen and co-authors have shown that the scaffolding effect of these proteins leads to the formation of stable $\mathrm{PI}(4,5) \mathrm{P}_{2}$ microdomains with reduced lateral diffusion in the membrane plane ${ }^{17,18}$. Since then, the list of proteins involved in the formation of $\mathrm{PI}(4,5) \mathrm{P}_{2}$ clusters has been extended to other endocytic proteins such as Epsin2, AP180, and the N-BAR domain proteins amphiphysin 1 and BIN $1^{19}$. So far, the formation of PI clusters has been mainly restricted to $\mathrm{PI}(4,5) \mathrm{P}_{2}$, possibly owing to its multiple regulatory functions at the plasma membrane. In addition, $\mathrm{PI}(4,5) \mathrm{P}_{2}$ is more abundant than other more elusive PI isoforms and has therefore been the focus of many studies for several years. However, we recently reported that the monophosphate PIs PI4P and PI5P can also be clustered ${ }^{19}$.

\section{PI clustering is a diffusion-driven process}

PI clustering has initially been proposed to originate from electrostatic interactions and, to a lesser extent, from hydrogen bonding between PI headgroups. PI molecules appear thus sequestered beneath positively charged surfaces, which results in a significant reduction of lateral diffusion in the membrane plane ${ }^{17}$. The number of PI molecules that interact with basic residues is determined by the negative net charge of the PIs at a given $\mathrm{pH}$. For instance, the charge of the $\mathrm{PI}(4,5) \mathrm{P}_{2}$ molecules at $\mathrm{pH} 3$ is $-1.5 \mathrm{e}$, whereas at $\mathrm{pH} 7.4$, which is close to the $\mathrm{pH}$ of the cytosol (7.2), it is $-4 \mathrm{e}^{20}$. For a N-BAR homodimer of charge $+8 \mathrm{e}$, one could estimate that at cytosolic $\mathrm{pH}$, the stoichiometry of PI-interacting molecules per protein module is $2: 1$, which gives an estimated 1.5-fold increase of local PI(4,5) $\mathrm{P}_{2}$. However, experimental studies have shown that the binding of the N-BAR module on PI-containing membranes induces a local enrichment of at least 10 -fold ${ }^{19}$. How could such a difference in the local PIs' enrichment be explained?

Theoretical studies have shown that the binding of a positively charged protein with a negatively charged membrane induces lipid demixing near to the protein surface ${ }^{19,21}$. This phenomenon is the result of the combination of electrostatic interactions and an entropic effect. Upon protein-membrane binding, charged lipids diffuse in the plane of the membrane towards the protein surface to preserve charge neutrality (Figure 2). In the case of monovalent lipids such as phosphatidylserine (PS), lipid demixing is almost negligible as a result of the fast $K_{\text {on }} / K_{\text {off }}$ rates between the protein and the membrane, which prevents charged lipids to locally segregate ${ }^{22}$ (Figure 2, left panel). However, for multivalent lipids such as some PI species, the transient interaction with a positively charged protein generates an electrostatic potential well, which results in a reduction of the $K_{\text {on }} / K_{\text {off }}$ rates and in protein diffusion. Consequently, transient demixing of PI molecules can take place ${ }^{22}$ (Figure 2, right panel). As shown by numerical simulations and consistent with the estimated $\sim 10$-fold increase from experimental data, PIs can cluster together up to nine lipid molecules per protein module. The trajectory of PI molecules in the plane of the membrane showed the existence of PIprotein dissociation events, thus pointing out that clustered PI molecules are not sequestered ${ }^{19}$. Importantly, this behavior is observed at initial physiological relevant concentrations of $1 \% \mathrm{PI}(4,5) \mathrm{P}_{2}$.

PI demixing has been reported in both flat and curved membranes. In the latter case, the segregation of PI molecules is likely to be amplified by membrane curvature since it is reported to significantly reduce protein diffusion ${ }^{23}$ and lipid dynamics ${ }^{17}$. This is in agreement with recent molecular simulations that show that clustering of lipids such as PIs and GM3 correlates with membrane curvature ${ }^{8}$.

\section{The "PI clustering" toolbox: electrostatic interactions and beyond}

Local segregation of PIs into submicron domains has been mostly described for proteins with the intrinsic property to polymerize on membranes, such as the BAR domain family. Proteins of the BAR family can sense and generate membrane curvature, owing to the scaffolding structure that results from the homodimerization of the BAR module. Association of BAR proteins with membranes takes place through electrostatic interactions between positively charged amino acids on the concave/convex face of the dimeric module and acidic phospholipids ${ }^{24}$. PI clustering has been reported for proteins with F-BAR, BAR, N-BAR, and I-BAR modules ${ }^{17-19}$. The tendency of multivalent PIs to engage lipid demixing over the monovalent PS provides BAR proteins with some specificity to generate PI subdomains at the plasma membrane, where $\mathrm{PI}(4,5) \mathrm{P}_{2}$ and $\mathrm{PI}(3,4,5) \mathrm{P}_{3}$ 

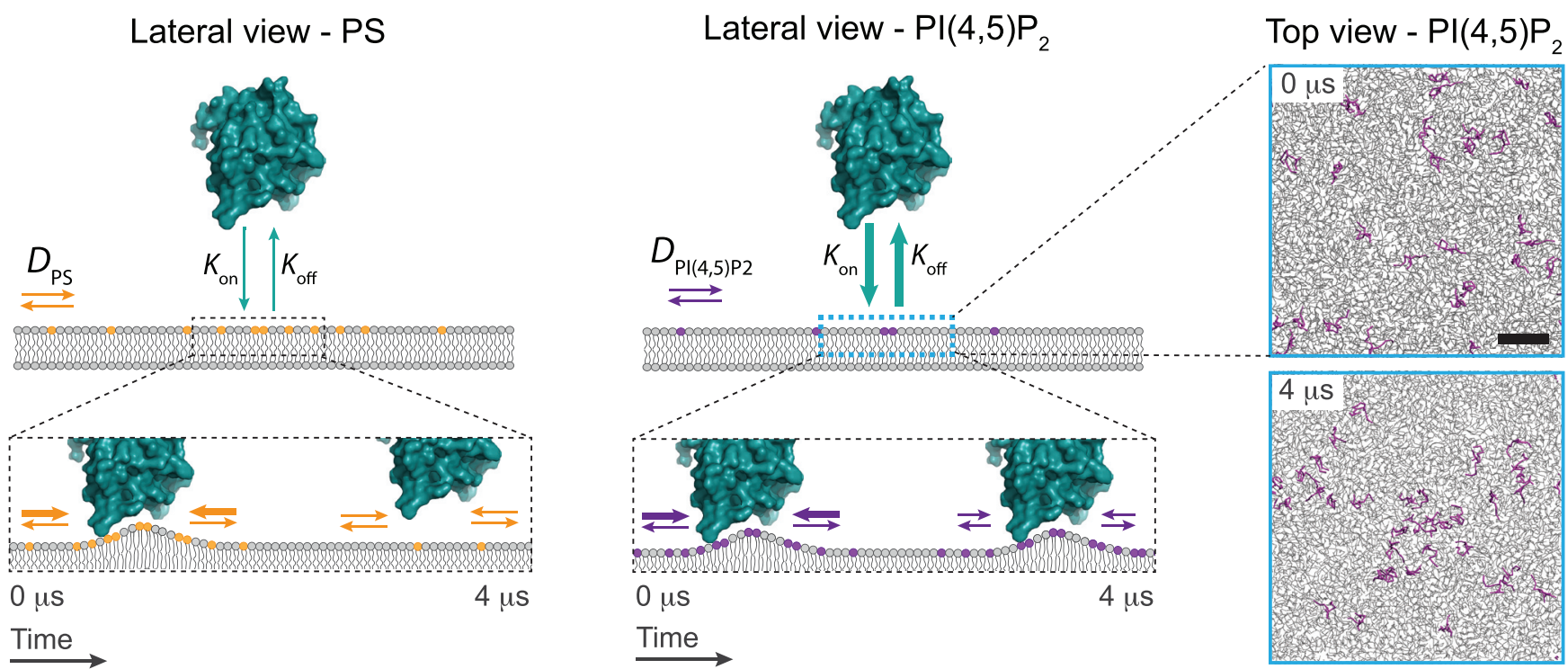

Figure 2. Schematic representation on how phosphoinositide (PI)-binding motifs can engage local demixing of Pls on cellular membranes. As an example, lateral view of the ENTH domain of Epsin (PDB code 1HOA) in cyan upon binding to a membrane that contains monovalent lipids such as phosphatidylserine (PS) (in orange, left panel) or $\mathrm{PI}(4,5) \mathrm{P}_{2}$ (in magenta, right panel). Cyan arrows represent the $K_{\text {on }} / K_{\text {off }}$ rates of the ENTH domain binding on membranes, being faster for $\mathrm{PS}$ over $\mathrm{PI}(4,5) \mathrm{P}_{2}$. As a result, transient demixing of $\mathrm{Pl}(4,5) \mathrm{P}_{2}$ molecules can take place. The diffusion of PS and $\mathrm{PI}(4,5) \mathrm{P}_{2}$ in the plane of the membrane is depicted by orange and magenta arrows, respectively. Right panel shows a top view of $\mathrm{PI}(4,5) \mathrm{P}_{2}$ clustering coarse-grain molecular dynamics simulations (as described in 19$)$ on spontaneous membrane biding of an ENTH domain. The panels are snapshots at $t=0 \mu s$ and $4 \mu$ s of the individual position of $\mathrm{PI}(4,5) \mathrm{P}_{2}$ molecules (in magenta) along the simulation. Scale bar, $1 \mathrm{~nm}$

are the predominant affected PI isoforms. According to the structural homology within members of the BAR superfamily, it is likely that the formation of PI-enriched microdomains could be a general feature of any protein hosting a BAR module. Combination of the BAR module with PI-binding motifs within the same protein might provide an additional layer of regulation and, possibly, production of monophosphate PI pools in other organelles than the plasma membrane, as observed in the case of $\mathrm{BIN} 1^{19}$. This suggests that the property of PI clustering might be extrapolated to some members of the sorting nexin (SNX) family holding a BAR module and a PX motif $^{25}$, although this link has yet to be established.

The clustering of PIs is, however, not necessarily associated with the intrinsic ability of proteins to self-assemble. Indeed, the transient segregation of PIs is likely to generate a positive feedback loop. As a result, proteins that selectively interact with PIs can locally accumulate on PI-enriched areas, independently of their ability to polymerize, as observed for the ENTH and ANTH domains ${ }^{19}$. Therefore, PI clustering seems to be a general property of proteins that directly interact with PIs via electrostatic interactions with more or less specificity for a given PI isoform. Accordingly, natively unstructured polybasic protein domains have also been shown to induce local segregation of PIs at the plasma membrane, as observed for MARCKS, GAP43, CAPS23, and syntaxin- $1 \mathrm{~A}^{10,13}$. The number of proteins that associate with acidic lipids at the plasma membrane through polybasic sequences is large $\mathrm{e}^{14,15}$. For instance, several small GTPases have been shown to interact with plasma membrane $\mathrm{PI}(3,4,5) \mathrm{P}_{3}$ and $\mathrm{PI}(4,5) \mathrm{P}_{2}$ by means of polybasic clusters ${ }^{26}$.
PI clustering might be solely limited to ionic protein-lipid interactions, although it is tempting to speculate that alternative or complementary mechanisms might take on the stabilization of PI pools. For instance, recent studies have shown that the pinning of the cytoskeleton on membranes preserves liquid-ordered and liquiddisordered (Lo-Ld) phase coexistence at physiological temperatures $\left(37^{\circ} \mathrm{C}\right)^{27,28}$. The polymerization of actin cytoskeleton was also shown to promote segregation of lipid phases in in vitro models ${ }^{29}$. These observations are in agreement with the "picket fence" model, which predicts that the cytoskeletal network might act as a diffusion barrier for lipids and proteins ${ }^{30}$. The exact partition of PI $(4,5) \mathrm{P}_{2}$ into Lo-Ld domains is not yet clear, but the depletion of cholesterol with methyl- $\beta$-cyclodextrin was shown to reduce $\mathrm{PI}(4,5) \mathrm{P}_{2}$ levels at the plasma membrane ${ }^{31}$. The partition of $\mathrm{PI}(4,5) \mathrm{P}_{2}$ to cholesterol-dependent domains was also reported using the targeting of a 5-phosphatase ${ }^{32}$. In addition, the sequestration of syntaxin-1A microdomains at sites of synaptic vesicle exocytosis in the plasma membrane was shown to require the formation of cholesterol and $\mathrm{PI}(4,5) \mathrm{P}_{2}$-mediated clusters, which are both distinct from lipid "rafts" 12,33 . An interesting observation is that Ld domains were found to align along actin fibers independently of the lipid phase to which actin was pinned ${ }^{28}$. This might be explained by local changes in membrane curvature induced by the actin network. Indeed, Ld domains appear to favor lipid sorting and membrane deformation $^{34}$. Recently, numerical simulations have shown that clustering of lipids such as $\mathrm{PI}(4,5) \mathrm{P}_{2}$ correlates with membrane curvature $^{8}$. The exact contribution of membrane curvature itself in PI clustering is not yet established, but lipid packing defects associated with membrane curvature might favor a better exposure of 
$\mathrm{PI}(4,5) \mathrm{P}_{2}$ headgroups ${ }^{19,35}$. Here, one will have to take into account in future experiments the nature of the fatty acids present on PI molecules, which might also impact on the rigidity and shape of the lipid bilayers to which they belong.

\section{PI clustering: a novel regulator of intracellular trafficking and signaling?}

Importantly, after PI clustering, protein-PI dissociation can still take place independently of the initial concentration of PIs ${ }^{19}$. This suggests that PI clusters are more dynamic than initially anticipated and that a given PI cluster could sequentially interact with different effectors. Thus, PI clustering induced by an upstream protein could favor the recruitment of a downstream PI-binding partner, providing a mechanism to coordinate trafficking or signaling events.

One process that PI clustering could regulate is clathrin-mediated endocytosis (CME). Indeed, the F-BAR, ANTH, ENTH, and N-BAR domains are present in central molecular players involved in $\mathrm{CME}^{36}$. All of these protein modules have been shown to engage local segregation of $\mathrm{PI}(4,5) \mathrm{P}_{2}{ }^{17,19}$, which is the key PI isoform in $\mathrm{CME}$. Therefore, PI clustering could participate in the spatiotemporal regulation of $\mathrm{CME}$ based on the affinity constant of the different protein intermediates and their interaction with $\mathrm{PI}(4,5) \mathrm{P}_{2}$. A hypothetical example of how PI clustering might operate in CME is shown in Figure 3, although the number of $\mathrm{PI}(4,5) \mathrm{P}_{2}$ effectors implicated in CME is much larger (see Table 1). The polymerization of the N-BAR module along the bud neck is likely to establish a diffusion barrier ${ }^{37}$, highly enriched in PIs, which would thereby be shielded from the activity of kinases and phosphatases. These features might be relevant at different stages of clathrin-coated vesicle biogenesis. Indeed, the metabolic evolution of PIs during CME has been shown to be important for the maturation of clathrin-coated vesicles $^{38}$. In addition, the segregation of lipid phases has been reported to generate sufficient line tension to induce membrane scission $^{39}$. It is therefore possible that the PI demixing induced by BAR proteins plays an additional role in line tension-mediated fission at the last stage of CME, as suggested by theoretical studies ${ }^{40}$.

It is tempting to propose that the coordinated action of PIs and scaffolding protein complexes, in particular BAR proteins, is a general feature of the biogenesis of transport vesicles ${ }^{67}$. For instance, the N-BAR protein Arfaptin 1 has been shown to participate in

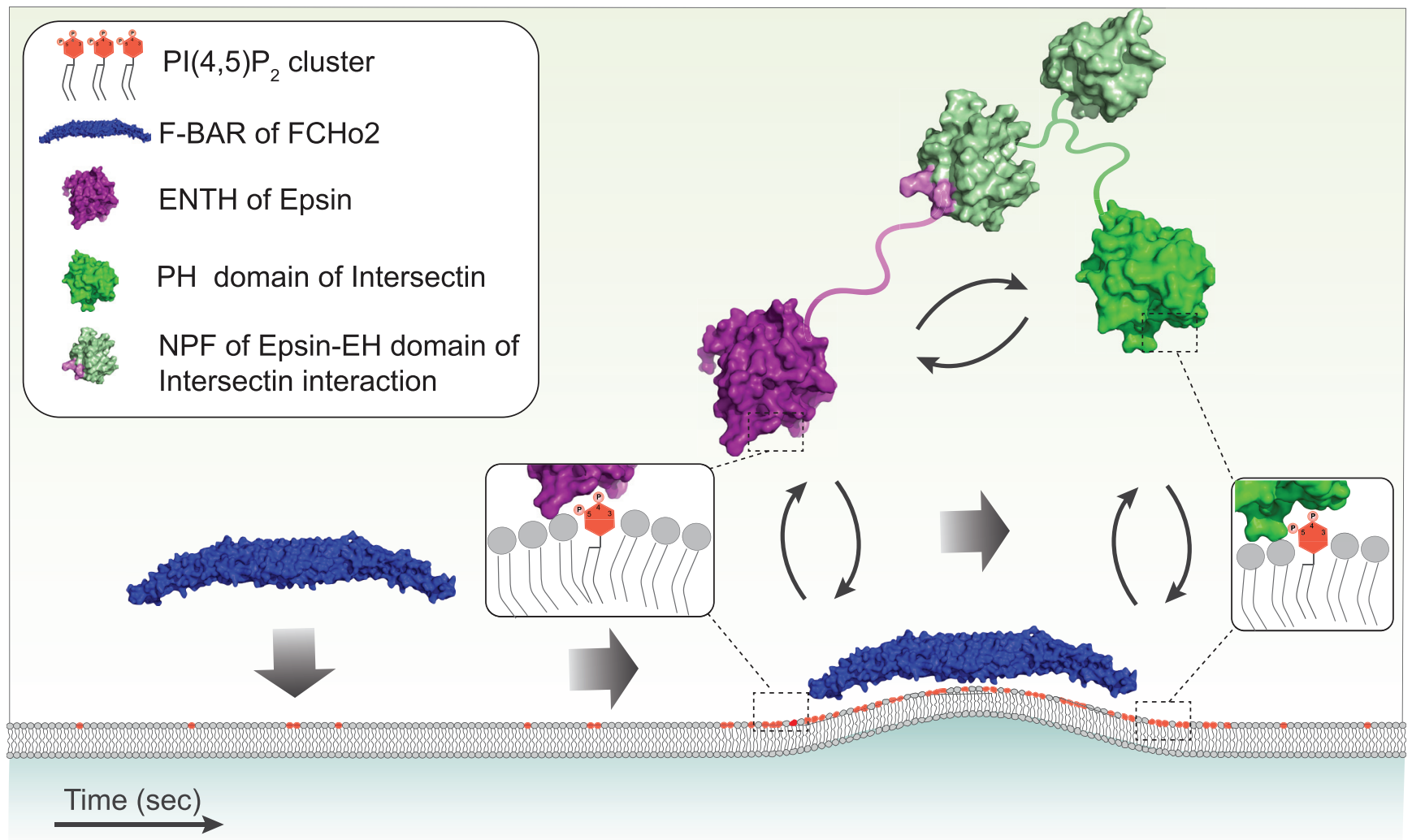

Figure 3. Schematics of the potential role of phosphoinositide (PI) clustering to coordinate cell trafficking events: example of the biogenesis of a clathrin-coated vesicle. The F-BAR domain (Protein Data Bank [PDB] code 2V0O) of FCHo2 binds to the plasma membrane, driving $\mathrm{PI}(4,5) \mathrm{P}_{2}$ segregation into clusters. The local $\mathrm{PI}(4,5) \mathrm{P}_{2}$ enrichment drives the binding of Epsin through the interaction of its ENTH domain (PDB code $1 \mathrm{HOA}$ ) with PI(4,5)P. The Asn-Pro-Phe (NPF) domain of Epsin can interact with the EH domain (PDB code 3FIA) of Intersectin, which in addition hosts a PH domain (PDB code $1 \mathrm{MAI}$ ) that binds to $\mathrm{PI}(4,5) \mathrm{P}_{2}$. The dynamics of the system is likely influenced by the affinity constant of the $\mathrm{PI}(4,5) \mathrm{P}_{2}$-binding motifs, which will determine the $\mathrm{K}_{\text {on }} / \mathrm{K}_{\text {off }}$ of $\mathrm{Pl}(4,5) \mathrm{P}_{2}$-mediated membrane binding, and by the affinity constant between the different protein domains. 
Table 1. PI(4,5) $\mathbf{P}_{2}$ effectors implicated in CME. The table shows an overview of all the possible options that exist in the $\mathrm{PI}(4,5) \mathrm{P}_{2}$-mediated protein recruitment during the different stages of $\mathrm{CME}$. Notice that although the interaction with $\mathrm{PI}(4,5) \mathrm{P}_{2}$ is mostly electrostatically driven, some effectors hold structured motifs with specific affinities/selectivity for $\mathrm{PI}(4,5) \mathrm{P}_{2}$. In addition, effectors can act as either monomers or larger assemblies, although $\mathrm{PI}(4,5) \mathrm{P}_{2}$ clustering can engage the local accumulation of proteins that typically do not self-assemble as a result of positive feedback ${ }^{19}$.

\begin{tabular}{|c|c|c|c|c|}
\hline $\begin{array}{l}\text { Mammalia } \\
\mathrm{n} \text { protein }\end{array}$ & Function & $\begin{array}{l}\mathrm{PI}(4,5) \mathrm{P}_{2} \\
\text { interaction }\end{array}$ & $\begin{array}{l}\text { Self- } \\
\text { assembly }\end{array}$ & References \\
\hline $\mathrm{FCHo} 1 / 2$ & Membrane curvature (F-BAR) & Charge dependent & Yes & $17,41,42$ \\
\hline AP2 & Adaptor complex & $\begin{array}{l}\alpha \text { subunit } \\
\text { C- } \mu 2 \text { subunit }\end{array}$ & No & 43,44 \\
\hline Intersectin & Scaffolding protein & $\mathrm{PH}$ domain & Yes & $45-47$ \\
\hline AP180, CALM & Adaptor of AP2 and clathrin & ANTH domain & No & 48,49 \\
\hline HIP1-HIP1R & Links actin to clathrin & ANTH domain & No & 49,50 \\
\hline Epsin & Membrane bending & ENTH domain & No & 49,51 \\
\hline Amphiphysin & Membrane curvature (N-BAR) & Charge dependent & Yes & $19,24,52$ \\
\hline Endophilin & Membrane curvature (N-BAR) & Charge dependent & Yes & 24,53 \\
\hline Syndapin & Membrane curvature (F-BAR) & Charge dependent & Yes & $17,54,55$ \\
\hline SNX 9/18 & Membrane curvature (BAR) & PX domain & Yes & 56,57 \\
\hline Dynamin & Scission & $\mathrm{PH}$ domain & Yes & $58-60$ \\
\hline OCRL & PI 5-phosphatase & $\mathrm{PH}$ domain & No & 61 \\
\hline Numb & Cargo adaptor (Notch) & PTB/PI domain & No & 62,63 \\
\hline Dab2 & Cargo adaptor (LDLR) & DH domain & No & $64-66$ \\
\hline $\mathrm{ARH}$ & Cargo adaptor (LDLR) & PTB/PI domain & No & 65,66 \\
\hline
\end{tabular}

the biogenesis of secretory storage granules through the interaction with PI4P at the trans-Golgi network ${ }^{68}$. The ArfGAP ASAP1 also carries a BAR module along with a PI-binding motif and has been shown to provide a platform to regulate Arf4 and Rab8/Rab11mediated targeting of rhodopsin transport carriers to cilium ${ }^{69}$. Finally, some members of the SNX family also hold a BAR module in addition to the characteristic PX domain, which typically binds to $\mathrm{PI}_{3} \mathrm{P}^{6}$. The SNX-BAR proteins are implicated in tubule-based endosomal sorting ${ }^{70}$. This includes the two retromer subunits SNX1 and SNX2, SNX5, and SNX6 or SNX4 among others ${ }^{71,72}$. One may speculate that the formation of PI clustering together with the binding affinity for different PI effectors might be linked to the ability of SNX-BAR proteins to define tubular endosomal subdomains.

PI clustering could also play an important role in the coordination of signaling events. Interestingly, the juxtamembrane segment of the EGFR, which is implicated in the activation of the receptor, is also composed of a cluster of basic residues that interact with $\mathrm{PI}(4,5) \mathrm{P}_{2}^{73,74}$. Indeed, natively unstructured polybasic protein domains have been shown to engage $\mathrm{PI}(4,5) \mathrm{P}_{2}$ clustering ${ }^{11}$. The interaction of the EGFR with $\mathrm{PI}(4,5) \mathrm{P}_{2}$ is required for the activation and downstream signaling of the receptor at the plasma membrane and seems also to regulate its fate in the endosomal compartments. The first observation that PI4P 5-kinase activity generating $\mathrm{PI}(4,5) \mathrm{P}_{2}$ pools was associated with the EGFR and required for appropriate activation and downstream signaling originates from the early $90 \mathrm{~s}^{75}$. Later studies demonstrated that $\mathrm{PI}(4,5) \mathrm{P}_{2}$ clustering induced by the binding and antiparallel dimerization of the juxtamembrane segments of two associated EGFRs can lead to the activation of the receptor even in the absence of ligand ${ }^{76}$. This property was suggested to be important at a high density of EGFR monomers $\left(>800 / \mu \mathrm{m}^{2}\right)$, as is often observed in aberrant activation of the receptor in cancers ${ }^{73,77}$. In this condition, formation of EGFR nanoclusters takes place as a result of the electrostatic interaction between $\mathrm{PI}(4,5) \mathrm{P}_{2}$ molecules at the plasma membrane and the juxtamembrane region of the receptor ${ }^{78}$.

Recent evidence demonstrates that $\mathrm{PI}(4,5) \mathrm{P}_{2}$ generated on endosomes is required for the appropriate sorting of active EGFR towards multivesicular bodies and further termination of the signal. This process relies on the recruitment of the endosomal type I $\gamma$ PIP kinase, PIPKI $\gamma \mathrm{i} 5$, that gets targeted to early endosomes by association with SNX5, an effector of $\mathrm{PI}(4,5) \mathrm{P}_{2}$. The kinase will then increase local pools of $\mathrm{PI}(4,5) \mathrm{P}_{2}$, also required for association of SNX5 with Hrs proteins that will then interact with ubiquitinated EGFR and ensure its proper sorting ${ }^{79}$.

It is noteworthy that most of the tyrosine kinase receptors of the EGFR family harbor a polybasic juxtamembrane domain that could play the same role in terms of ligand free activation or sorting and signal transduction (e.g. insulin-like growth factor 1 receptor [IGF1R], vascular endothelial growth factor receptor [VEGFR], 
platelet-derived growth factor receptor [PDGFR], and fibroblast growth factor receptor 1 [FGFR1], among others $)^{76}$. Although PI clustering being a general feature of membrane-associated polybasic domains provides an attractive hypothesis to activate receptors and trigger signaling, work is still needed to define whether it is a broad mechanism or applies only to some specific proteins.

\section{Conclusions}

The spatiotemporal remodeling of PI pools within distinct organelles is an intrinsic feature that makes possible the orchestration of PI-mediated cellular functions. Indeed, PIs are constantly subjected to the activity of PI-metabolizing enzymes and must be in addition accessible to effectors. Because the lateral diffusion of lipid molecules within the membrane plane is extremely fast, PI clustering comes up as a realistic mechanism to locally preserve newly metabolized PI pools on cellular membranes. Indeed, Balla and co-workers already anticipated that PI4P replenishment from the Golgi was not essential to preserve the plasma membrane pool, although it does contribute to its formation ${ }^{80}$. Irvine and co-authors also showed that the maintenance of the steadystate pool of $\mathrm{PI}(4,5) \mathrm{P}_{2}$ at the plasma membrane does not require localization of its synthetic precursor PI4P on the same cellular compartment $^{81}$. It is tempting to speculate that PI clusters might work as potential platforms to coordinate PI-mediated protein interactions or as molecular beacons, as previously proposed ${ }^{13}$. Nevertheless, the myriad of protein modules capable of engaging PI clustering is becoming broad. Based on structural homologies, one might predict that the list will progressively increase. An interesting feature to point out is that PI clustering seems to be a general mechanism for either multivalent or monophosphate PIs ${ }^{19}$. The precise regulatory role of PI clustering in trafficking and signal transduction has still to be established, but it certainly opens up exciting perspectives in the field. For instance, PI clustering might orchestrate the different steps in carrier biogenesis. Also, the ability of cellular receptors to engage PI clustering might determine their sorting to the appropriate compartment. The physiological implication of PI clustering in living organisms has yet to be established. Recent studies have already shown that the oligomerization of Sec14-nodulin proteins controls the localization of $\mathrm{PI}(4,5) \mathrm{P}_{2}$ and signaling landscape in polarized membrane morphogenesis in Arabidopsis thaliana root hairs ${ }^{82,83}$. Despite the role of PIs in many cellular processes, certain PI isoforms and functions have often been elusive due to the lack of detection or labeling strategies, which is typically limited to the use of PI-binding motifs with all of the associated side effects. The development of novel experimental strategies capable of detecting the intrinsic dynamics of PIs or of exploiting the recently developed sub-100nm life cell imaging techniques ${ }^{84}$ will be key to unraveling the regulatory role of PI clustering.

\section{Author contributions}

All authors contributed equally to this work.

\section{Competing interests}

The authors declare that they have no competing interests.

\section{Grant information}

This work was supported by grants from the Agence Nationale de la Recherche (ANR) (ANR-13-BSV2-0004-01) and the ERC (MYODYN, \# 339847).

The funders had no role in study design, data collection and analysis, decision to publish, or preparation of the manuscript.

\section{Acknowledgments}

We thank Dr. Stefano Vanni (Institut de Pharmacologie Moléculaire et Cellulaire, UMR 7275, France) for kindly performing and providing the numerical simulations shown in Figure 2.
1. Di Paolo G, De Camilli P: Phosphoinositides in cell regulation and membrane dynamics. Nature. 2006; 443(7112): 651-7. PubMed Abstract | Publisher Full Text

2. Moser von Filseck J, Čopič A, Delfosse V, et al:: INTRACELLULAR TRANSPORT Phosphatidylserine transport by ORP/Osh proteins is driven by phosphatidylinositol 4-phosphate. Science. 2015; 349(6246): 432-6. PubMed Abstract | Publisher Full Text

3. F Balla T: Phosphoinositides: tiny lipids with giant impact on cell regulation Physiol Rev. 2013; 93(3): 1019-137. PubMed Abstract | Publisher Full Text | Free Full Text | F1000 Recommendation

4. Berridge MJ, Irvine RF: Inositol phosphates and cell signalling. Nature. 1989; 341(6239): 197-205.

PubMed Abstract | Publisher Full Text

5. De Matteis MA, Godi A: PI-loting membrane traffic. Nat Cell Biol. 2004; 6(6): 487-92. PubMed Abstract | Publisher Full Text

6. Kutateladze TG: Translation of the phosphoinositide code by PI effectors. Nat Chem Biol. 2010; 6(7): 507-13.

PubMed Abstract | Publisher Full Text | Free Full Text

7. van Meer G, Voelker DR, Feigenson GW: Membrane lipids: where they are and how they behave. Nat Rev Mol Cell Biol. 2008; 9(2): 112-24. PubMed Abstract | Publisher Full Text | Free Full Text
8. Koldsø $\mathrm{H}$, Shorthouse D, Hélie J, et al:: Lipid clustering correlates with membrane curvature as revealed by molecular simulations of complex lipid bilayers. PLoS Comput Biol. 2014; 10(10): e1003911. PubMed Abstract | Publisher Full Text | Free Full Text

9. Krauss $M$, Haucke V: Phosphoinositide-metabolizing enzymes at the interface between membrane traffic and cell signalling. EMBO Rep. 2007; 8(3): 241-6. PubMed Abstract | Publisher Full Text | Free Full Text

10. Laux T, Fukami K, Thelen M, et al:: GAP43, MARCKS, and CAP23 modulate $\mathrm{PI}(4,5) \mathrm{P}_{2}$ at plasmalemmal rafts, and regulate cell cortex actin dynamics through a common mechanism. J Cell Biol. 2000; 149(7): 1455-72. PubMed Abstract | Publisher Full Text | Free Full Text

11. McLaughlin S, Murray D: Plasma membrane phosphoinositide organization by protein electrostatics. Nature. 2005; 438(7068): 605-11. PubMed Abstract | Publisher Full Text

12. F van den Bogaart G, Meyenberg K, Risselada HJ, et al:: Membrane protein sequestering by ionic protein-lipid interactions. Nature. $2011 ; 479(7374): 552-5$. PubMed Abstract | Publisher Full Text | Free Full Text | F1000 Recommendation

13. F Honigmann A, van den Bogaart G, Iraheta E, et al:: Phosphatidylinositol 4 5-bisphosphate clusters act as molecular beacons for vesicle recruitment. Nat Struct Mol Biol. 2013; 20(6): 679-86. PubMed Abstract | Publisher Full Text | Free Full Text | F1000 Recommendation 
14. Bogdanov M, Dowhan W, Vitrac H: Lipids and topological rules governing membrane protein assembly. Biochim Biophys Acta. 2014; 1843(8): 1475-88. PubMed Abstract | Publisher Full Text | Free Full Text

15. Li L, Shi X, Guo X, et al.: lonic protein-lipid interaction at the plasma membrane: what can the charge do? Trends Biochem Sci. 2014; 39(3): 130-40. PubMed Abstract | Publisher Full Text

16. Carvalho K, Ramos L, Roy C, et al:: Giant unilamellar vesicles containing phosphatidylinositol(4,5)bisphosphate: characterization and functionality. Biophys J. 2008; 95(9): 4348-60. PubMed Abstract | Publisher Full Text | Free Full Text

17. F Zhao H, Michelot A, Koskela EV, et al:: Membrane-sculpting BAR domains generate stable lipid microdomains. Cell Rep. 2013; 4(6): 1213-23. PubMed Abstract | Publisher Full Text | Free Full Text | F1000 Recommendation

18. F Saarikangas J, Zhao H, Pykäläinen $\mathrm{A}$, et al:: Molecular mechanisms of membrane deformation by I-BAR domain proteins. Curr Biol. 2009; 19(2): 95-107. PubMed Abstract | Publisher Full Text | F1000 Recommendation

19. Picas L, Viaud J, Schauer K, et al.: BIN1/M-Amphiphysin2 induces clustering of phosphoinositides to recruit its downstream partner dynamin. Nat Commun 2014; 5: 5647.

PubMed Abstract | Publisher Full Text

20. Ellenbroek WG, Wang YH, Christian DA, et al:: Divalent cation-dependent formation of electrostatic PIP ${ }_{2}$ clusters in lipid monolayers. Biophys J. 2011; 101(9): 2178-84

PubMed Abstract | Publisher Full Text | Free Full Text

21. F Khelashvili G, Weinstein H, Harries D: Protein diffusion on charged membranes: a dynamic mean-field model describes time evolution and lipid reorganization. Biophys J. 2008; 94(7): 2580-97.

PubMed Abstract | Publisher Full Text | Free Full Text | F1000 Recommendation

22. Golebiewska U, Gambhir A, Hangyás-Mihályné G, et al:: Membrane-bound basic peptides sequester multivalent (PIP $)$, but not monovalent (PS), acidic lipids. Biophys J. 2006; 91(2): 588-99.

PubMed Abstract | Publisher Full Text | Free Full Text

23. Domanov YA, Aimon S, Toombes GE, et al:: Mobility in geometrically confined membranes. Proc Natl Acad Sci U S A. 2011; 108(31): 12605-10. PubMed Abstract | Publisher Full Text | Free Full Text

24. F Peter BJ, Kent HM, Mills IG, et al:: BAR domains as sensors of membrane curvature: the amphiphysin BAR structure. Science. 2004; 303(5657): 495-9. PubMed Abstract | Publisher Full Text | F1000 Recommendation

25. Cullen PJ: Endosomal sorting and signalling: an emerging role for sorting nexins. Nat Rev Mol Cell Biol. 2008; 9(7): 574-82.

PubMed Abstract | Publisher Full Text

26. $\mathrm{F}$ Heo WD, Inoue $\mathrm{T}$, Park WS, et al.: $\mathbf{P I}(\mathbf{3}, \mathbf{4}, \mathbf{5}) \mathbf{P}_{3}$ and $\mathbf{P I}(\mathbf{4}, \mathbf{5}) \mathbf{P}_{2}$ lipids target proteins with polybasic clusters to the plasma membrane. Science. 2006; 314(5804): 1458-61.

PubMed Abstract | Publisher Full Text | Free Full Text | F1000 Recommendation

27. F Arumugam S, Petrov EP, Schwille P: Cytoskeletal pinning controls phase separation in multicomponent lipid membranes. Biophys J. 2015; 108(5): 1104-13. PubMed Abstract | Publisher Full Text | Free Full Text | F1000 Recommendation

28. F Honigmann A, Sadeghi S, Keller J, et al:: A lipid bound actin meshwork organizes liquid phase separation in model membranes. eLife. 2014; 3: e01671. PubMed Abstract | Publisher Full Text | Free Full Text | F1000 Recommendation

29. F Liu AP, Fletcher DA: Actin polymerization serves as a membrane domain witch in model lipid bilayers. Biophys J. 2006; 91(11): 4064-70. PubMed Abstract | Publisher Full Text | Free Full Text | F1000 Recommendation

30. Kusumi A, Nakada C, Ritchie K, et al.: Paradigm shift of the plasma membrane concept from the two-dimensional continuum fluid to the partitioned fluid: high-speed single-molecule tracking of membrane molecules. Annu Rev Biophys Biomol Struct. 2005; 34: 351-78. PubMed Abstract | Publisher Full Text

31. F Kwik J, Boyle S, Fooksman D, et al: Membrane cholesterol, lateral mobility, and the phosphatidylinositol 4,5-bisphosphate-dependent organization of cell actin. Proc Natl Acad Sci U S A. 2003; 100(24): 13964-9.

PubMed Abstract | Publisher Full Text | Free Full Text | F1000 Recommendation

32. Johnson CM, Chichili GR, Rodgers W: Compartmentalization of phosphatidylinositol 4,5-bisphosphate signaling evidenced using targeted phosphatases. J Biol Chem. 2008; 283(44): 29920-8. PubMed Abstract | Publisher Full Text | Free Full Text

33. Lang T, Bruns D, Wenzel D, et al.: SNAREs are concentrated in cholesteroldependent clusters that define docking and fusion sites for exocytosis. EMBO J. 2001; 20(9): 2202-13.

PubMed Abstract | Publisher Full Text | Free Full Text

34. Manneville JB, Casella JF, Ambroggio E, et al.: COPI coat assembly occurs on liquid-disordered domains and the associated membrane deformations are limited by membrane tension. Proc Natl Acad Sci U S A. 2008: 105(44): 16946-51. PubMed Abstract | Publisher Full Text | Free Full Text

35. F Vanni $\mathrm{S}$, Hirose $\mathrm{H}$, Barelli $\mathrm{H}$, et al.: A sub-nanometre view of how membrane curvature and composition modulate lipid packing and protein recruitment. Nat Commun 2014: 5: 4916 .

PubMed Abstract | Publisher Full Text | F1000 Recommendation
36. McMahon $\mathrm{HT}$, Boucrot $\mathrm{E}$ : Molecular mechanism and physiological functions of clathrin-mediated endocytosis. Nat Rev Mol Cell Biol. 2011; 12(8): 517-33. PubMed Abstract | Publisher Full Text

37. Prévost $\mathrm{C}$, Zhao $\mathrm{H}$, Manzi J, et al.: IRSp53 senses negative membrane curvature and phase separates along membrane tubules. Nat Commun. 2015; 6: 8529 PubMed Abstract | Publisher Full Text | Free Full Text

38. F Posor Y, Eichhorn-Gruenig M, Puchkov D, et al:: Spatiotemporal contro of endocytosis by phosphatidylinositol-3,4-bisphosphate. Nature. 2013; 499(7457): 233-7.

PubMed Abstract | Publisher Full Text | F1000 Recommendation

39. F Roux A, Cuvelier D, Nassoy $P$, et al.: Role of curvature and phase transition in lipid sorting and fission of membrane tubules. EMBO J. 2005; 24(8): 1537-45. PubMed Abstract | Publisher Full Text | Free Full Text | F1000 Recommendation

40. $\quad \mathrm{F}$ Liu J, Sun Y, Drubin DG, et al:: The mechanochemistry of endocytosis. PLOS Biol. 2009; 7(9): e1000204.

PubMed Abstract | Publisher Full Text | Free Full Text | F1000 Recommendation

41. Henne WM, Kent HM, Ford MG, et al:: Structure and analysis of FCHo2 F-BAR domain: a dimerizing and membrane recruitment module that effects membran curvature. Structure. 2007; 15(7): 839-52.

PubMed Abstract | Publisher Full Text

42. $\mathrm{F}$ Henne $\mathrm{WM}$, Boucrot $\mathrm{E}$, Meinecke $\mathrm{M}$, et al.: $\mathrm{FCHo}$ proteins are nucleators of clathrin-mediated endocytosis. Science. 2010; 328(5983): 1281-4. PubMed Abstract | Publisher Full Text | Free Full Text | F1000 Recommendation

43. F Collins BM, McCoy AJ, Kent HM, et al:: Molecular architecture and functional model of the endocytic AP2 complex. Cell. 2002; 109(4): 523-35. PubMed Abstract | Publisher Full Text | F1000 Recommendation

44. F Höning S, Ricotta D, Krauss M, et al.: Phosphatidylinositol-(4,5)-bisphosphate regulates sorting signal recognition by the clathrin-associated adaptor complex AP2. Mol Cell. 2005; 18(5): 519-31.

PubMed Abstract | Publisher Full Text | F1000 Recommendation

45. Yamabhai M, Hoffman NG, Hardison NL, et al.: Intersectin, a novel adaptor protein with two Eps15 homology and five Src homology 3 domains. J Biol Chem. 1998; 273(47): 31401-7. PubMed Abstract | Publisher Full Text

46. Hussain NK, Jenna S, Glogauer M, et al.: Endocytic protein intersectin-I regulates actin assembly via Cdc42 and N-WASP. Nat Cell Biol. 2001; 3(10): 927-32.

PubMed Abstract | Publisher Full Text

47. Adams A, Thorn JM, Yamabhai M, et al:: Intersectin, an adaptor protein involved in clathrin-mediated endocytosis, activates mitogenic signaling pathways. $J$ Biol Chem. 2000; 275(35): 27414-20. PubMed Abstract | Publisher Full Text

48. Ford MG, Pearse BM, Higgins MK, et al:: Simultaneous binding of Ptdlns(4,5) $P_{2}$ and clathrin by AP180 in the nucleation of clathrin lattices on membranes. Science. 2001; 291(5506): 1051-5. PubMed Abstract | Publisher Full Text

49. Stahelin RV, Long F, Peter BJ, et al.: Contrasting membrane interaction mechanisms of AP180 N-terminal homology (ANTH) and epsin N-terminal homology (ENTH) domains. J Biol Chem. 2003; 278(31): 28993-9.

PubMed Abstract | Publisher Full Text

50. Engqvist-Goldstein AE, Kessels MM, Chopra VS, et al.: An actin-binding protein of the Sla2/Huntingtin interacting protein 1 family is a novel component of clathrin-coated pits and vesicles. J Cell Biol. 1999; 147(7): 1503-18. PubMed Abstract | Publisher Full Text | Free Full Text

51. F Ford MG, Mills IG, Peter BJ, et al:: Curvature of clathrin-coated pits driven by epsin. Nature. 2002; 419(6905): 361-6. PubMed Abstract | Publisher Full Text | F1000 Recommendation

52. Takei K, Slepnev VI, Haucke V, et al.: Functional partnership between amphiphysin and dynamin in clathrin-mediated endocytosis. Nat Cell Biol. 1999; 1(1): 33-9.

PubMed Abstract | Publisher Full Text

53. Ringstad N, Gad H, Löw P, et al.: Endophilin/SH3p4 is required for the transition from early to late stages in clathrin-mediated synaptic vesicle endocytosis. Neuron. 1999; 24(1): 143-54.

PubMed Abstract | Publisher Full Text

54. Qualmann B, Kelly RB: Syndapin isoforms participate in receptor-mediated endocytosis and actin organization. J Cell Biol. 2000; 148(5): 1047-62. PubMed Abstract | Publisher Full Text | Free Full Text

55. Wang $Q$, Navarro MV Peng G et al: Molecular mechanism of membrane constriction and tubulation mediated by the F-BAR protein Pacsin/Syndapin. Proc Natl Acad Sci U S A. 2009; 106(31): 12700-5. PubMed Abstract | Publisher Full Text | Free Full Text

56. Lundmark R, Carlsson SR: Sorting nexin 9 participates in clathrin-mediated endocytosis through interactions with the core components. $J$ Biol Chem. 2003; 278(47): 46772-81

PubMed Abstract | Publisher Full Tex

57. Pylypenko O, Lundmark R, Rasmuson E, et al:: The PX-BAR membrane-remodeling unit of sorting nexin 9. EMBO J.2007; 26(22): 4788-800.

PubMed Abstract | Publisher Full Text | Free Full Text 
58. F Bashkirov PV, Akimov SA, Evseev Al, et al.: GTPase cycle of dynamin is coupled to membrane squeeze and release, leading to spontaneous fission. Cell. 2008; 135(7): 1276-86.

PubMed Abstract | Publisher Full Text | Free Full Text | F1000 Recommendation

59. F Faelber K, Posor Y, Gao S, et al:: Crystal structure of nucleotide-free dynamin. Nature. 2011; 477(7366): 556-60.

PubMed Abstract | Publisher Full Text | F1000 Recommendation

60. Klein DE, Lee A, Frank DW, et al:: The pleckstrin homology domains of dynamin isoforms require oligomerization for high affinity phosphoinositide binding J Biol Chem. 1998; 273(42): 27725-33. PubMed Abstract | Publisher Full Text

61. Mao Y, Balkin DM, Zoncu R, et al:: A PH domain within OCRL bridges clathrinmediated membrane trafficking to phosphoinositide metabolism. EMBO J. 2009; 28(13): 1831-42.

PubMed Abstract | Publisher Full Text | Free Full Text

62. Dho SE, French MB, Woods SA, et al:: Characterization of four mammalian numb protein isoforms. Identification of cytoplasmic and membraneassociated variants of the phosphotyrosine binding domain. J Biol Chem. 1999; 274(46): 33097-104. PubMed Abstract | Publisher Full Text

63. Salcini $\mathrm{AE}$, Confalonieri $\mathrm{S}$, Doria $\mathrm{M}$, et al:: Binding specificity and in vivo targets of the EH domain, a novel protein-protein interaction module. Genes Dev. 1997; 11(17): 2239-49.

PubMed Abstract | Publisher Full Text | Free Full Text

64. Mishra SK, Keyel PA, Hawryluk MJ, et al.: Disabled-2 exhibits the properties of a cargo-selective endocytic clathrin adaptor. EMBO J. 2002; 21(18): 4915-26. PubMed Abstract | Publisher Full Text | Free Full Text

65. Maurer ME, Cooper JA: The adaptor protein Dab2 sorts LDL receptors into coated pits independently of AP-2 and ARH. J Cell Sci. 2006; 119(Pt 20): 4235-46. PubMed Abstract | Publisher Full Text

66. Yun M, Keshvara L, Park CG, et al.: Crystal structures of the Dab homology domains of mouse disabled 1 and 2. J Biol Chem. 2003; 278(38): 36572-81. PubMed Abstract | Publisher Full Text

67. Vicinanza M, D'Angelo G, Di Campli A, et al:: Function and dysfunction of the $\mathbf{P}$ system in membrane trafficking. EMBO J. 2008; 27(19): 2457-70. PubMed Abstract | Publisher Full Text | Free Full Text

68. F Cruz-Garcia D, Ortega-Bellido M, Scarpa M, et al.: Recruitment of arfaptins to the trans-Golgi network by $\mathrm{PI}(4) \mathrm{P}$ and their involvement in cargo export. EMBO J. 2013; 32(12): 1717-29

PubMed Abstract | Publisher Full Text | Free Full Text | F1000 Recommendation

69. Wang J, Morita Y, Mazelova J, et al: The Arf GAP ASAP1 provides a platform to regulate Arf4- and Rab11-Rab8-mediated ciliary receptor targeting. $E M B O \mathrm{~J}$. 2012; 31(20): 4057-71. PubMed Abstract | Publisher Full Text | Free Full Text

70. F van Weering JR, Sessions RB, Traer CJ, et al:: Molecular basis for SNX-BARmediated assembly of distinct endosomal sorting tubules. EMBO J.2012; 31(23): 4466-80

PubMed Abstract | Publisher Full Text | Free Full Text | F1000 Recommendation

71. Bonifacino JS, Hurley JH: Retromer. Curr Opin Cell Biol. 2008; 20(4): 427-36. PubMed Abstract | Publisher Full Text | Free Full Text
72. $F$ van Weering JR, Verkade P, Cullen PJ: SNX-BAR-mediated endosome tubulation is co-ordinated with endosome maturation. Traffic. 2012; 13(1): 94-107. PubMed Abstract | Publisher Full Text | F1000 Recommendation

73. F Arkhipov A, Shan $\mathrm{Y}$, Das R, et al: Architecture and membrane interactions of the EGF receptor. Cell. 2013; 152(3): 557-69. PubMed Abstract | Publisher Full Text | Free Full Text | F1000 Recommendation

74. F Abd Halim KB, Koldsø H, Sansom MS: Interactions of the EGFR juxtamembrane domain with $\mathrm{PIP}_{2}$-containing lipid bilayers: Insights from multiscale molecular dynamics simulations. Biochim Biophys Acta. 2015; 1850(5): 1017-25.

PubMed Abstract | Publisher Full Text | Free Full Text | F1000 Recommendation

75. Cochet C, Filhol O, Payrastre B, et al.: Interaction between the epidermal growth factor receptor and phosphoinositide kinases. J Biol Chem. 1991; 266(1): 637-44.

PubMed Abstract

76. Michailidis IE, Rusinova R, Georgakopoulos A, et al:: Phosphatidylinositol-4, 5-bisphosphate regulates epidermal growth factor receptor activation. Pflugers Arch. 2011; 461(3): 387-97.

PubMed Abstract | Publisher Full Text | Free Full Text

77. F Endres NF, Das R, Smith AW, et al.: Conformational coupling across the plasma membrane in activation of the EGF receptor. Cell. 2013; 152(3): 543-56. PubMed Abstract | Publisher Full Text | Free Full Text | F1000 Recommendation

78. Wang Y, Gao J, Guo X, et al:: Regulation of EGFR nanocluster formation by ionic protein-lipid interaction. Cell Res. 2014; 24(8): 959-76. PubMed Abstract | Publisher Full Text | Free Full Text

79. F Sun Y, Hedman AC, Tan X, et al.: Endosomal type l $\gamma$ PIP 5-kinase controls EGF receptor lysosomal sorting. Dev Cell. 2013; 25(2): 144-55 PubMed Abstract | Publisher Full Text | Free Full Text | F1000 Recommendation

80. F Szentpetery Z, Várnai P, Balla T: Acute manipulation of Golgi phosphoinositides to assess their importance in cellular trafficking and signaling. Proc Natl Acad Sci U S A. 2010; 107(18): 8225-30. PubMed Abstract | Publisher Full Text | Free Full Text | F1000 Recommendation

81. F Hammond GR, Fischer MJ, Anderson KE, et al:: $\mathbf{P I} 4 \mathbf{P}$ and $\mathbf{P I}(4,5) \mathbf{P}_{2}$ are essential but independent lipid determinants of membrane identity. Science. 2012; 337(6095): 727-30.

PubMed Abstract | Publisher Full Text | Free Full Text | F1000 Recommendation

82. F Ghosh R, de Campos MK, Huang J, et al:: Sec14-nodulin proteins and the patterning of phosphoinositide landmarks for developmental control of membrane morphogenesis. Mol Biol Cell. 2015; 26(9): 1764-81. PubMed Abstract | Publisher Full Text | Free Full Text | F1000 Recommendation

83. F Vincent $P$, Chua $M$, Nogue $F$, et al: A Sec14p-nodulin domain phosphatidylinositol transfer protein polarizes membrane growth of Arabidopsis thaliana root hairs. J Cell Biol. 2005; 168(5): 801-12. PubMed Abstract | Publisher Full Text | Free Full Text | F1000 Recommendation

84. F Li D, Shao L, Chen BC, et al:: ADVANCED IMAGING. Extended-resolution structured illumination imaging of endocytic and cytoskeletal dynamics. Science. 2015; 349(6251): aab3500.

PubMed Abstract | Publisher Full Text | Free Full Text | F1000 Recommendation 


\section{Open Peer Review}

\section{Current Peer Review Status:}

\section{Editorial Note on the Review Process}

Faculty Reviews are review articles written by the prestigious Members of Faculty Opinions. The articles are commissioned and peer reviewed before publication to ensure that the final, published version is comprehensive and accessible. The reviewers who approved the final version are listed with their names and affiliations.

\section{The reviewers who approved this article are:}

\section{Version 1}

\section{Peter Mayinger}

Division of Nephrology \& Hypertension and Department of Cell \& Developmental Biology, Oregon Health \& Science University, Portland, OR, USA

Competing Interests: No competing interests were disclosed.

2. Volker Haucke Leibniz-Institut für Molekulare Pharmakologie (FMP), Berlin, Germany

Competing Interests: No competing interests were disclosed.

\section{Vytas A Bankaitis}

Department of Molecular and Cellular Medicine, Texas A\&M Health Science Center, College Station, TX, USA

Competing Interests: No competing interests were disclosed.

4. Tamas Balla

Molecular Signal Transduction NICHD, National Institutes of Health, Bethesda, MD, USA

Competing Interests: No competing interests were disclosed. 
The benefits of publishing with F1000Research:

- Your article is published within days, with no editorial bias

- You can publish traditional articles, null/negative results, case reports, data notes and more

- The peer review process is transparent and collaborative

- Your article is indexed in PubMed after passing peer review

- Dedicated customer support at every stage

For pre-submission enquiries, contact research@f1000.com 